\title{
OVERVIEW Of Japanese LaNGUage in UpPer Secondary Education AND SCHOOL CURRICULUM IN ROMANIA
}

\author{
Mariana LUNGU \\ Ion Creanga National College, Romania \\ lungu.mariana27@yahoo.com
}

\begin{abstract}
In this paper, I focus my attention on the problem of teaching Japanese as part of compulsory subjects in an upper secondary education to pupils aged between 15 to 19 . This article starts out with a brief overview of the Romanian education system and the current state of Japanese teaching in the upper secondary education. As compared to other educational curricula, the Romanian education system focuses on competency-based curriculum emphasizing the applicability of knowledge and the development of competences in an integrated and inter-disciplinary approach. The Japanese Language is part of that curricular area named as Language and Communication. In the Romanian educational system, the process of teaching the Japanese language starts from lower secondary school and continues to upper secondary and then to university level. In the lower secondary school, pupils study the Japanese Language as an elective subject, while in the upper secondary school, they learn Japanese as a mandatory subject of the core curriculum and as an elective one of school-based curriculum. Next, attention is paid to outline the current situation of teaching Japanese in the upper-secondary education system, providing details of our curricula, types of subjects, and specific features of Japanese classes. Forms of Japanese language education vary greatly, as well as their target students and objectives. However, the focus of all is a balanced education in the four language skills: reading, writing, listening and speaking. In addition to the Japanese language study, Japanese syllabi provide cultural and general education to learn the properties in Japanese Society and about contemporary culture.
\end{abstract}

Keywords: upper secondary education; curriculum structure; competence; language and communication

\section{Povzetek}

Prispevek se osredotoča na poučevanje japonščine kot obveznega predmeta na višji sekundarni ravni (15-19 let). Članek najprej na kratko predstavi izobraževalni sistem v Romuniji in poda oris trenutnega stanja poučevanja japonščine na tej ravni. Romunski izobraževalni sistem zagovarja učne načrte, ki temeljijo na pridobivanju veščin. $S$ celovitim in interdisciplinarnim pristopom poudarja uporabno vrednost znanja in razvoj kompetenc. Japonščina tako sodi na širše področje jezik in komunikacija. Proces poučevanja japonščine se prične na nižji sekundarni ravni (12-14 let) in se preko višje sekundarne oziroma srednješolske ravni nadaljuje do univerzitetne ravni. Na nižji sekundarni ravni lahko učenci izberejo japonščino kot izbirni predmet, na višji sekundarni ravni pa postane japonščina obvezni predmet osnovnega učnega načrta ali izbirni predmet posameznega

Acta Linguistica Asiatica, 8(1), 2018.

ISSN: 2232-3317, http://revije.ff.uni-lj.si/ala/

DOI: 10.4312/ala.8.1.101-110 
šolskega programa. V nadaljevanju članek predstavi trenutno stanje poučevanja japonščine na višji sekundarni ravni, pri čemer podrobno opiše učne načrte, vrste predmetov in izpostavi posebne značilnosti pouka japonščine. Poučevanje japonščine se pojavlja v zelo raznovrstnih oblikah, saj so tudi ciljne skupine učencev in osnovne opredelitve predmeta različne. A ne glede na raznolikost je fokus vedno na uravnoteženem razmerju štirih jezikovnih spretnosti: bralnega razumevanja, slušnega razumevanja, pisnega izražanja in govornega sporočanja. Učni načrti za japonski jezik poleg omenjenih vsebin zajemajo tudi splošne in kulturološke vsebine, ki se navezujejo na značilnosti japonske družbe in sodobne kulture.

Ključne besede: srednješolsko izobraževanje; struktura učnega načrta; kompetence; jezik in komunikacija

\section{Educational system and national teaching guideline in Romania}

The Romanian school education system has a 4-4-4 structure. That is, students have 4 years of primary education in elementary school, 4 years of lower secondary education in junior high school, and 4 years of upper secondary education in senior high school, for a total of 12 years of school education. After completing their primary and secondary education, students may continue on to an institution of higher education.

Early childhood (0-6 years) is formed in the ante (0-3 years) and preschool (3-6 years), comprising a small group, middle group and high group. Primary school includes I - IV and the preparatory class is the first class in the primary. Secondary education is part of compulsory education. It includes lower secondary or secondary education classes V - VIII. High school IX-XII includes the following departments and profiles: theoretic type, profiles humanities, and sciences; technological route with technical profiles, services, natural resources and environmental protection; vocational branch, military profiles, theological, sports, arts, and teaching.

All schools in Romania have foreign language programs. Students must acquire at least one foreign language at an advanced level and the second one at a more basic level. In other cases there are more than two foreign languages available to study and the student can choose from several. Many schools also offer bilingual courses.

In terms of language skills in a foreign language, Romania is one of the EU countries where compulsory curriculum provides learning two foreign languages. For upper secondary education, Romania is among the countries with the highest average number of foreign languages learned in school. However, it is difficult to assess in a comparative perspective the language skills of students in Romania, because our country did not participate in the European survey on language competences, launched by the European Commission in 2008 (Ministerul Educatiei Nationale, 2014).

Students in secondary education can be transferred from one school level to another, from one class to another, from one profile to another and from one pathway 
to another, as determined by the methodology developed by the Ministry of Education. Educational pluralism is one of the attributes of Romanian school education.

In Romania, public or private schools offer the alternative educational system (Step by Step, Waldorf, Freinet, Montessori etc.) that complement the main education system, opening new perspectives of teaching and pedagogical approach to learning. Education for pupils in secondary education is predominantly in the official language, cf. Romanian, but also in the language of students belonging to national minorities where ethnic communities are large, or in international languages (usually in the case of private schools by type international). During enrollment in secondary education, children are beneficiaries of state allowance for children under the law (Ministerul Educatiei Nationale, n.d.).

Higher education in Romania is provided by both public and private higher education institutions. These include universities, academies, and colleges organized into specialized departments. The first stage of university-level studies provides a short-term (three-year) or a long-term (four- to six-year, according to the field of study) diploma, which is awarded as a Diploma de Licenta. The second stage of universitylevel education is the master's level, in which students can earn a Diplomă de Studii Aprofundate after conducting one to two years of research. The third stage of university-level studies is the doctoral level (only one form exists: doctor of science), which can last for three to six years. Candidates who have passed the examination for a doctoral degree (a doctorate) are awarded the Diploma de Doctor în Stiinţe. Public higher education institutions are coordinated by the Ministry of Education and Research under the principle of university autonomy. Private higher education is an alternative to public education and is subject to an accreditation process (Population Europe Resource Finder \& Archive (PERFAR), n.d.).

\section{Teacher training and curriculum}

Teachers must pass several examinations to advance in their careers called Uniform training for teachers. Preschool and primary school teachers are required to attend a pedagogical lyceum, while secondary school teachers for lower secondary education need a degree from short-term higher education, and secondary-school teachers for upper secondary a degree from long-term higher Education. All the above-mentioned categories of teachers must have completed the pedagogical module (during university courses or at least 5 year after graduation) and the special training programmes corresponding to each qualification. A teacher's professional development consists of three stages, namely the on-the-job certification (Definitivat) after three years of teaching, the didactic grade II, and the didactic grade I (the highest form). 


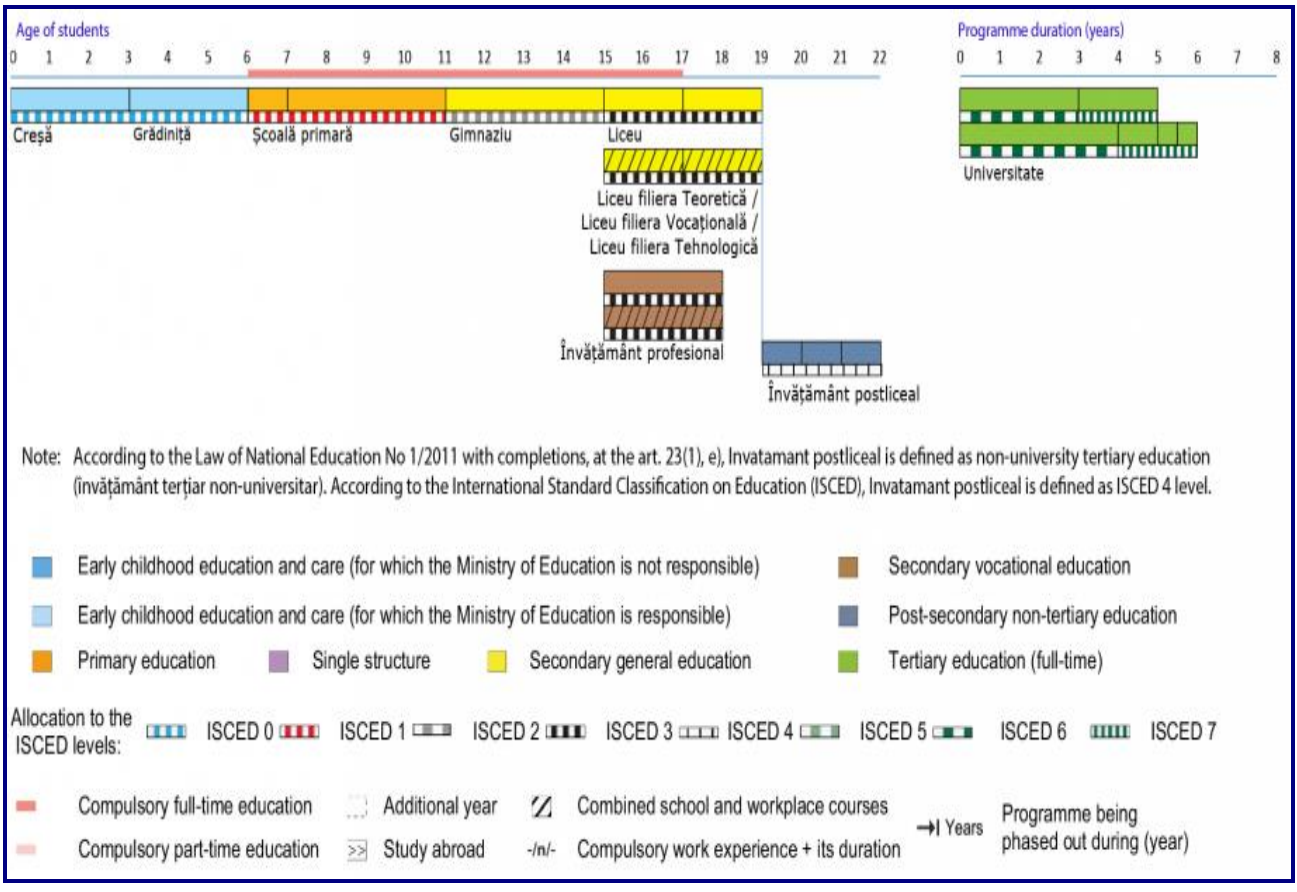

Figure 1: Romanian educational system.

(Source: Eurydice, 2016)

The national curriculum, established by the Ministry of Education, consists of seven curricular areas: language and communication, mathematics and natural science, people and society, the arts, physical education, technologies, and counseling and guidance. This core curriculum represents $75 \%$ of all of the courses offered, while the rest of the courses follow school-based curricula (based on specialization) (PERFAR, n.d.).

The curriculum includes the contents of primary and secondary education, having a common core for all schools of the same type and elements that depend on the decision of each school or high school. Framework plans, that include compulsory, elective and optional subjects, as well as the minimal and maximal number of classes and the school curricula are devised by national special commissions and are endorsed by the National Council for the Curriculum and sanctioned by the Ministry. At the level of primary and secondary education, alternative textbooks are used, and teachers have the right to choose and recommend the textbook to their pupils (Romania Ministry of Education and Research, 2001).

The Romanian curriculum is built upon a principle system, cf. curriculum as a system. As such it is designed according to:

- the educational ideal of the Romanian school;

- the psychological learning rules; the students' age and individual characteristics; 
- the students' potential (discovered, stimulated and brought to value by teachers): divergent and critical thinking, imagination, creativity, etc.;

- the social and cultural dynamics of the community;

Curriculum as learning activities:

- different styles, techniques and teaching procedures for different learning rhythms;

- learning activities are based upon intellectual effort and self discipline;

- individual and group work;

- the final target is developing skills, capacities, competences, knowledge, attitudes, and conduct;

- the students' educational interests are the gist of efficiency in order to be actively integrated in the social life of community;

Curriculum as teaching principles:

- diverse and efficient learning situations, in accordance to the educational objectives;

- stimulating and sustaining the students' motivation for permanent learning;

- discovering and developing the students' skills in accordance to their educational needs and interests;

- teaching as a forming process (not only teaching or informing, but mainly developing competences, skills, conducts);

- inter/intra - disciplinary transfers;

- connection between educational activities and communitarian life.

Like any other curricular program, the Romanian system is seen as a sum of agents (educators and educated), objectives, educational contents, educational strategies, time, space and material resources, and finally evaluation strategies (Nadrag \& Soare, 2013).

\section{Organisation of school year and week system in upper-secondary education}

Organisation of the school year for upper secondary education is decided yearly by the Ministry of Education, Research,Youth and Sports. The structure of the school year takes several aspects into consideration. Those are a balanced distribution of the school-days and holidays, the specificity of the climate in Romania, and the respect for the religious beliefs of the population. The National Curriculum is established by the Ministry of Education, Research, Youth and Sports and specifies for each pre-university education level and grade: the total minimum and maximum number of classes per week; the minimum and maximum number of classes per week for each subject within the common core curriculum; the minimum and maximum number of classes per week 
dedicated to optional subjects/activities. Within the framework set by the structure of the school year and the National Curriculum, each pre-university education institution has the full responsibility to establish the weekly and daily timetables for each grade.

The school year in Romania for upper secondary education comprises two semesters, three periods of holidays during the school year, and a summer holiday. The exact calendar of the school year is established each year through Order of the Minister of Education. According to the Ministerial Order and as provided by the in-force legislation, schools can request County School Inspectorates amendments of the school year calendar due to objective reasons: special weather conditions, specificity of the area (agricultural activities), natural calamities, schools with the majority of the pupils of other beliefs than the Orthodox one, etc. The County School Inspectorates can approve such requests subject to the condition that all pupils attend the total number of school-weeks and corresponding school-days as established by the Ministerial Order.

The weekly (5-day week system) and daily timetables for upper secondary education are established by the administration council of the schools subsequent consultations with the teachers and the parents/the pupils and based on the following criteria: the number of classes per week and subject within the range established by the Frame Plans for each grade, and the minimum and maximum number of classes per week established by the Frame Plans for each grade. According to the provisions of the in-force Frame Plans, the total number of classes per week and grade for day-schooling upper secondary education depends on the education level, branch of study, profile, and specialization/vocational qualification.

Upper-secondary education is usually organized 5-day week system. Lessons are 50 minutes long and are followed by 10 minutes breaks. In schools functioning in double shifts due to insufficient schooling capacity, certain classes start their programme from 12,1 or $2 \mathrm{pm}$. Due to the fact that a given class studies either in the morning or in the afternoon, usually there is no lunch break specifically set in the daily timetables of the schools. The only exception to this situation is where schools organize at their own initiative after-school programmes for the pupils (Eurydice, n.d.).

\section{Ion Creanga National College}

Ion Creanga National College was founded in 1926 and includes the following departments: Romanian Language, Mathematics, People and Society, EnglishJapanese, French-German, Science, Informatics, Religion-Arts-Physical Education, Careers Counselling and guidance, Examination Center: Cambridge English Language Assessment-Authorized Center; European Computer Driving License. 


\subsection{Japanese language}

Japanese is studied in our institution either as a main or a second language, together with other languages like English, French or German. More than 250 pupils study Japanese in our college. This year a new class of Science added Japanese to its program. Responding to the needs of our pupils, we have established a wide range of elective subjects, such as Japanese Culture, Kanji, Kaiwa and Japanese Testing. The core subjects are those of Japanese Language and the elective courses are changeable every year. The local curricular offer, found in the school-based curriculum, is set based on a consultation with parents, pupils and other educational partners, with the condition that they are approved by the inspectorate and the administration council of each school.

\subsubsection{A core subject}

\section{Japanese language}

Objectives: developing competences based on the pupils' direct voluntary action (exercises, practical work, etc.) and interactive methods (didactic games, learning through dramatization, etc.).

As teaching materials, the following textbooks are used for classes: Minna no Nihongo shokyū I, Minna no Nihongo shokyū II, Genki II - An Integrated Course in Elementary Japanese.

Evaluation: pupils are evaluated through a variety of assessments: chapter tests, semestrial test (teza), portfolio (grammar cards, kanji cards, individual worksheets, vocabulary on semantic fields).

\subsubsection{Elective subjects}

\section{Japanese culture}

Objectives: brief description for periods of Japanese history, annual festivals and events, cultural concepts, rites of life, school and education, daily life, family, food, home and community, work and career, leisure, hobbies, etc.

As teaching materials, the following textbooks are used for classes: Moons, Months and Seasons-Pre-Intermediate Japanese Reader, The Kodansha Bilingual Encyclopedia of Japan.

Evaluation: pupils are evaluated through a variety of assessments: short quizzes, chapter tests, projects, power-point presentations.

\section{Kanji}

Objectives: to develop an integrated knowledge of kanji so that they can read and comprehend authentic and semi-authentic materials effectively on their own by using 
cognitive memory strategies, mnemonic devices and illustrated context, association between the past knowledge of kanji characters and new kanji.

As teaching materials, the following textbooks are used for classes: Basic Kanji Book I \& II.

Evaluation: pupils are evaluated through a variety of assessments: chapter tests, portfolio (kanji cards, individual worksheets).

\section{Kaiwa (Conversation)}

Objectives: initiate or respond to short everyday conversations, request information and respond to requests on a variety of topics, ask and give preferences, offer and respond to suggestions, requests, or invitation, get the gist and understand the details of a text on a concrete topic.

As teaching materials, the following textbooks are used for classes: Minna no Nihongo shokyū I, Minna no Nihongo shokyū II, Genki II - An Integrated Course in Elementary Japanese.

Evaluation: pupils are evaluated through a variety of assessments such as role-play, mini-speech, and dramatization.

\section{Japanese testing}

Objectives: to provide support for pupils wanting to take Japanese Language Proficiency Test (JLPT); to enable pupils to develop and master the key skills required for the Nihongo Nōryoku Shiken (JLPT). A very important aspect which stimulated us to initiate this elective course is the advantage for the graduate exam; JLPT N3 is recognized by the minister of education and equivalate Language Competence for Baccalaureate.

As teaching materials, the following textbooks are used for classes: Gōkaku Dekiru 4-5, Nihongo So-Matome JLPT N3, JLPT N5, N4 Japanese Lauguage Proficiency Test Official Book Trial Examination, Nihongo Challenge N4 Grammar Reading JLPT.

Evaluation: pupils are evaluated through a variety of assessments such as chapter tests, portfolio (grammar cards for each level, kanji cards for each level, individual worksheets).

\section{Evaluation and quality in education}

To the traditional evaluation methods - the oral evaluation, the written tests, the practical tests - the alternative (complementary) evaluation methods have been added - the project, the file, the report, the investigation, the systematic observation of the pupils' behavior. In order to enhance the objectivity level of the evaluation tests, particular attention was paid to the evaluation tests based on objective items - 
multiple choice items, double choice items, pair type items - semi-objective items and open answer items. The reform of the evaluation system has taken into account as main evaluation instruments, depending on the age of the pupils and the specific of each discipline, the written tests at the end of the semester, practical activities in sciences, interviews, the files containing the work of the pupils over the entire semester.

Quality in education is assured through several processes such as planning and concrete realization of results, monitoring results, internal assessment, external assessment, and ongoing improvement of results. In order to undertake external assessment, two agencies are established: The Romanian Agency for Quality Assurance in Higher Education, ARACIS, and The Romanian Agency for Quality Assurance in PreUniversity Education, ARACIP. ARACIP is an independent public institution, of national interest, which possesses juridical personality and its own budget, and functioning rules and regulation are established by the Government.

\section{Future perspective}

Challenges remain related to guarantee the cultivation of whole pupils' key competencies. It is also required to increase the variety of methods when teaching Japanese, and also to create opportunities for pupils to discover Japanese culture by themselves. Last but not least, it is also necessary for a teacher to be responsive to learners' needs in order to make them reach their full potential.

\section{References}

Banno, E., Ohno, Y., Sakane, Y., Shinagawa, C., \& Tokashiki, K. (1999). Genki II: An Integrated Course in Elementary Japanese. Tokyo: Kinokuniya book store.

Eurydice (2016). Structure of the national education system. Retrieved from https://webgate.ec.europa.eu/fpfis/mwikis/eurydice/index.php/Romania:Overview

Eurydice (n.d.) Romania. Organisation of General Upper Secondary Education. Retrieved from https://webgate.ec.europa.eu/fpfis/mwikis/eurydice/index.php/Romania:Organisation o f General Upper Secondary Education\#Types of Institution

Japan Foundation. (2012). Jlpt N4 Japanese Lauguage Proficiency Test Official Book Trial Examination Questions. Bonjinsha.

Japan Foundation. (2012). Jlpt N5 Japanese Lauguage Proficiency Test Official Book Trial Examination Questions. Bonjinsha.

Kano, C., Takenaka, H., Ishii, E., \& Shimizu, Y. (1989). Basic Kanji Book I \& II. Tokyo: Bonjinsha. Kokusai Nihongo Kenkyūjo. (1992). Tanoshiku yomeru Nihon no kurashi jūni kagetsu: Moons, Months and Seasons A Pre-intermediate Japanese Reader. Tokyo: Apurikotto. 
Ministerul Educatiei Nationale (2014). Romanian Education for all Review Report. Bucharest.

Retieved from http://unesdoc.unesco.org/images/0023/002303/230309e.pdf

Ministerul Educatiei Nationale (n.d.). Retrieved from http://edu.ro/

Minna no Nihongo: I and II. (1998). Tokyo: 3A Network.

Nadrag, L., \& Soare, A. (2013) The Romanian Curriculum Within the European Educational Framework. Ovidius University Press. Retrieved from http://www.diacronia.ro/ro/indexing/details/A3739/pdf

Population Europe Resource Finder \& Archive (PERFAR) (n.d.) Educational Policies: Romania (2014). Retrieved from http://www.perfar.eu/policy/education/romania

Romania Ministry of Education and Research (2001). The Romanian Education System. The National Report. Bucharest. Retrieved from

http://www.ibe.unesco.org/International/ICE/natrap/Romania.pdf

Sasaki, H., \& Matsumoto, N. (2010). Nihongo So-Matome JLPT N3. Ask Publishing.

The Kodansha Bilingual Encyclopedia of Japan (English and Japanese Edition) (1998).

Kodansha USA Inc.

Yamabe, M. (2010). Nihongo Challenge N4 Grammar Reading JLPT. Tokyo: Asuku. 